\title{
Modification of the Internal Transport in the Tyre Factory
}

\author{
Zbigniew Matuszak ${ }^{1, *}$, Damian Sokołowski ${ }^{2}$, Marek Jaśkiewicz ${ }^{3}$, Branislav Šarkan ${ }^{4}$, \\ and Józef Stokłosa ${ }^{5}$ \\ ${ }^{1}$ Maritime University of Szczecin, Faculty of Marine Engineering, ul. Wały Chrobrego 1-2, 70-500 \\ Szczecin, Poland \\ ${ }^{2}$ Maritime University of Szczecin, Faculty of Economics and Transport Engineering, ul. H. \\ Pobożnego 11, 70-507 Szczecin Poland \\ ${ }^{3}$ Kielce University of Technology, Faculty of Mechatronics and Mechanical Engineering, al. \\ Tysiąclecia Państwa Polskiego 7, 25-314 Kielce, Poland \\ ${ }^{4}$ University of Žilina, Faculty of Operation and Economics of Transport and Communications, \\ Department of Road and Urban Transport, Univerzitná 1, 01026 Žilina, Slovakia \\ ${ }^{5}$ University of Economics and Innovation in Lublin, ul. Projektowa 4, 20-209 Lublin, Poland
}

\begin{abstract}
The production plant of tyres and rubber goods has been characterized in the article. The production process structure in general as well as the production process of tyres has been presented. The analysis of the internal transport system used in the production process of large tyres (OTR - Off The Road). The modification of the present transport system used in the large tyres production has been proposed. Both systems: the present one and the modified one have been compared using SWOT method (Strengths, Weaknesses, Opportunities, Threats). Not only the advantages but also the critical remarks concerning the proposed system have been enumerated.
\end{abstract}

\section{Introduction}

Internal transport as an element of the production and storing system underlies production targets and tasks present in the factory. It requires specific rules and principles of functioning.

The organisation of the internal transport should be adjusted to the specificity of a given factory, and what is more it should ensure safe and reliable movement of loads at the minimum costs. Effective organisation of internal transport in a factory should guarantee transfer of certain amount of goods on shortest possible ways, at the maximum use and minimum wear of means of transport.

Information and decision flows are strongly connected to the technical systems realizing physical material flows in the field of transport [1-3].

Looking at the internal transport from the perspective of the system allows for cheaper and better management of transport structures. Using methods and techniques of system analysis we can solve the problems of the internal transport more rationally because they

*Corresponding author: z.matuszak@am.szczecin.pl 
analyse the whole scope of transport activities from the single means of transport to the transport system when material flow is completed with information flow [4-6].

An efficient system of managing internal transport resources, human resources as well as material resources, is necessary for collision-free and efficient course of production processes.

The modification of the internal transport system of the factory was presented on the example of one of the leading tyre manufacturers in Poland.

The company is one of the key tyre and rubber goods manufacturers. They produce different tyre types, such as: large tyres (OTR - Off the Road), truck tyres (TBR), delivery car tyres (AGR), aircraft tyres, tyres for agricultural and industrial equipment. The company also manufactures rubber and rubber and metal semi-finished goods, like rubber compounds, capes, rubber fibres, mats, inner tubes. The company is also involved in the contract production of special materials for the Polish Armed Forces but the information about the production details cannot be disclosed.

On the company premises there is a Development Centre of the Tyre Industry established in 1957. It deals with the analysis of tyres and rubber goods as well as research works on the construction and manufacturing technology of rubber-fibre products carrying high loads and untypical tyre types. The Centre belongs to the company therefore all the products manufactured in the company are analysed and certified there without the need for using external centres for this purpose. The Centre also offers the possibility of assigning approval numbers to the products for other companies.

The whole company covers the area of 12 hectare, with its facilities occupying $66850 \mathrm{~m}^{2}$, including office spaces, storage infrastructure, production floors and research buildings.

\section{Description of company's production}

The factory manufactures the following product groups:

- tyres: large (OTR) for the industry (earthmoving equipment, road works machines and mining machinery); for trucks and delivery cars (TBR), for fork lift trucks and industrial trucks, for aircrafts and helicopters, for agricultural equipment;

- semi-finished goods: rubber compounds; capes, tyre cords; rubber fabrics;

- other products: protectors; inner tubes; shock absorbers; rubberised wheels; mats; rubber end stops;

- special products for the military.

The first group includes large OTR tyres (Off-The-Road), which are used in special equipment and vehicles outside the public roads. They are used in the industry for: wheel loaders, loading and output loaders, dump trucks, wheel tractor-scrapers, cranes, portal cranes, container gripping devices, diggers, and forest works devices. These are tyres over $0.28 \mathrm{~m}$ wide, and their height, depending on the type varies from $1 \mathrm{~m}$ to $2.5 \mathrm{~m}$. The tyres can weigh from few hundred kilograms up to few tones.

\section{Production infrastructure}

The production infrastructure in a described factory is very complex. The production itself takes place on a few production lines and different stages of the process are strongly interconnected.

The premises of the factory occupy $66850 \mathrm{~m}^{2}$, which includes: production area $23400 \mathrm{~m}^{2}$, raw materials warehouses $-2500 \mathrm{~m}^{2}$, finished goods area $-3000 \mathrm{~m}^{2}$, additional 
warehouses - $6600 \mathrm{~m}^{2}$. On the company premises there are also car parks and multipurpose yards.

Factory structure includes mixing plant and rolling mill, where semi-finished goods, including rubber are manufactured. In other buildings there is a production of finished goods, meaning: OTR tyres, aircraft tyres, special materials, TBR tyres and fork lift trucks/ agricultural tyres.

Production division results from the fact that different types of tyres require different production equipment. There are also separate buildings dedicated for the production for the request of Polish Armed Forces.

The company has got an extensive machine park, which includes, among others: injection moulding machines, hydraulic press, extruders, autoclaves and special equipment and machinery used for preparing the surface for rubber coating. A wide range of devices allows for realization of mass orders as well as special ones.

Every production of a final product begins from the delivery of raw materials or semifinished goods required for production. They are then connected together (and packed) and given a final shape.

Rubber is a main semi-finished good in a factory; it consists mainly of india rubber which along with soot, sulphur, oils, boosters and other additives creates a paste which is blended in a mixer. Such a compound is seasoned and underlies quality control. Vulcanisation process is all about pouring a compound of right raw materials in high temperature (over $150^{\circ} \mathrm{C}$ ) onto the rollers called calenders in the rolling mill. Then this rubber is rolled into special flaps which are then interlaid with a special paper. Such a rubber is a semi-finished good which is either used in further production or sold as such. So rubber production consists of two stages: weighing and composing a compound as well as vulcanisation (rolling mill).

Tyre production, on the other hand, includes four different stages: two initial ones look similar to rubber production stages, since a tyre consists mainly of rubber.

A second stage includes preparation of a cord made of nylon fibres (network of fibres inside a tyre) and construction of bead wire (element clamping a tyre against the rim) and other additional materials, like band or filler. A cord, also named as technical fabric is coated from both sides with a slim film of a proper rubber compound. Depending on the material used we distinguish different cords: nylon, viscose, polyester, glass, and steel. A cord is manufactured on the device called calender, and the process itself is called calendaring. Then a ready-made cord is cut into pieces. Both wide and narrow rubber pieces of a tyre undergo calendaring.

This is followed by tyre building, which is based on joining all the elements in order to achieve a raw tyre ready for vulcanisation. This is how a raw tyre, which then undergoes quality control, is made.

The last stage of tyre production is called vulcanisation. It is based on placing raw tyres in special moulds, in vulcanising presses where, under high pressure of membrane and high temperature, they are pressed against a mould. This is how a final shape and look of a tyre is achieved. A ready-made tyre undergoes another quality control test.

In the company they produce radial and diagonal tyres (the difference between those two lies in the arrangement of cord, tubed tyres (marked as TT) and tubeless tyres (marked as TL).

The other rubber and metal-rubber goods, although are produced in smaller amounts than tyres and do not belong to the main line of products, represent a significant part of company's sales. The production of shock absorbers, rubber end stops and membranes is based on the similar stages like tyre production. First stage includes supplying the semiproduct, meaning rubber, then the production made by specialised machines: injection 
moulding machines, extruders, hydraulic presses and autoclaves starts. Rubber is an elastic material, prone to high temperatures what enables us to shape it anyhow.

The production in the factory takes place in three-shifts, the company currently produces 250 thousand tyres a year but still the production capacity is much higher, which is over 544 thousand tyres a year.

\section{Internal transport characteristics in the company}

Internal transport infrastructure is quite extensive since flexible connections between the following production stages of rubber products are required.

In the internal transport they use groups of means of transport used in production process as well as during warehousing and storage. Some of the means of transport are used in both phases.

Means of close transport at the production include: band conveyors, bucket conveyors, roller conveyors, tractors, trains, different trucks used during handling of semi-finished goods at the production stage.

Means of internal transport used during warehousing and storage on the other hand comprise of hand pallet trucks, fork lift trucks, electrical platform trucks, and pallet transport trucks. Due to the untypical character of production many devices of close transport have a non-standard design. This design of trucks was done on the request of the company itself.

A finished good - in this case OTR tyres - is transported by the fork lift truck, with the use of special methods, or by transport platform trucks.

The first method requires using a hook and transport belts; second one assumes putting a tyre on the forks of a fork lift truck; the third one (the most common) is based on using a special rotary gripper for tyre transport; and the last method (developed by the company) consists in using a gripper of a special profile which is placed inside a tyre.

\section{Analysis of the internal system}

Material flow in a production plant starts from the place where the material is delivered by the external transport. It goes through the warehousing station, already transported by the means of close transport until it is unloaded. Then the material undergoes machining and assembly steps until it is stored in the warehouse again or it is immediately sent as a finished-good.

In the company a mixed material flow is used. In the first stage of production it is a continuous flow, based on band and bucket conveyors, and in the further stages the means of closed transport are used.

In the analysis of transport process examination we calculate what follows [1]:

- labour consumption of the material and information flow process, taking means of transport, equipment and human labour into account;

- whatever is needed to realize the process of means of transport and people, taking schedule of cycles and processes into consideration.

The material undergoes transport movements, so called transport cycles which are performed by the means of close transport during production process. During rubber production in the factory there are 7 up to 8 transport cycles, assuming that the material has been stored in the warehouse. A rubber is a semi-finished good, used in further production therefore the transport cycle of the final product is longer, which is over 8 cycles. Counting it together with rubber production, the production of a tyre requires minimum 16 transport cycles. 
Transport cycle is based on the serial production structure, where production machines are placed according to the technological process, and the whole production process is done on the beat. Unfortunately, this type of production has significant drawbacks: the longest operation imposes the time of its duration on the whole cycle, and the breakdown of one of the devices inhibits work of the whole system. Therefore, the number of devices and machines in the company is greater than the maximum demand for them.

Table 1 presents the data for the analysis of the means of internal transport for OTR tyres production.

Table 1. Using means of transport during OTR tyres production. Source: authors

\begin{tabular}{|c|c|c|c|c|}
\hline \multirow{2}{*}{ No. } & \multirow{2}{*}{ Means of transport } & \multicolumn{2}{|c|}{ Usage $[\%]$} & \multirow{2}{*}{ Sum $[\%]$} \\
\hline & & Production & Warehousing & \\
\hline 1. & Band conveyors & $30 \%$ & - & $30 \%$ \\
\hline 2. & Bucket conveyors & $30 \%$ & - & $30 \%$ \\
\hline 3. & $\begin{array}{l}\text { Platform truck with a drawbar for treaded } \\
\text { tyre transport + hand lift truck }\end{array}$ & $20 \%$ & $10 \%$ & $30 \%$ \\
\hline 4. & $\begin{array}{l}\text { Special hand transport truck for cope and } \\
\text { other material transport }\end{array}$ & $15 \%$ & - & $20 \%$ \\
\hline 5. & $\begin{array}{l}\text { Special transport truck of I TYPE or II } \\
\text { TYPE for bead wire transport }\end{array}$ & $10 \%$ & - & $15 \%$ \\
\hline 6. & $\begin{array}{l}\text { Truck/ special platform for packed tyres } \\
\text { transport }\end{array}$ & $20 \%$ & - & $20 \%$ \\
\hline 7. & $\begin{array}{l}\text { Overhead one-track conveyor for transport } \\
\text { of packed tyres to the press }\end{array}$ & $10 \%$ & - & $10 \%$ \\
\hline 8. & Tractor + platform (bellows) & $20 \%$ & - & $20 \%$ \\
\hline 9. & Platform transport truck for mould transport & $5 \%$ & $20 \%$ & $25 \%$ \\
\hline 10. & Electrical platform truck or fork lift truck & $20 \%$ & $20 \%$ & $40 \%$ \\
\hline
\end{tabular}

The table has been compiled on the basis of data about the means of transport used at the production of OTR tyres made available to the authors. The usage of the devices and machines expressed as a percentage means the ratio of the equipment used to the maximum possibilities of usage of this equipment. Usage of vulcanising presses remains on the level of $40 \%$, and usage of human resources on the level of $70 \%$.

Band and bucket conveyors are in fact used in $60 \%$ since the rubber they produce is used also on the other production lines, but it is also sold as a semi-finished good.

Internal transport devices are used whenever they are needed in a given time. Currently OTR tyres production constitutes $20-30 \%$ of the whole production in the company and it used only $30 \%$ of means of transport and $40 \%$ of machine capacity (so whenever a greater demand appears, it is possible to double the production).

The fragmented production structure and employing the internal transport employees hinders the cost analysis of the close transport and optimum usage of the costs. According to the data made available by the company the authors know that the factory employs 40 people on the positions connected to the internal transport. When dividing these people into departments (production lines), there are only five people for one department and five people responsible for warehousing of the finished goods. 
In order to make sure that internal transport is handled properly, by the sufficient number of people, the company shifts some employees from the positions where there is temporarily no demand for work (for instance, when the production demand is low) to different departments.

Figure 1 presents the current structure of the OTR tyres production system. The graph shows that three press stations are provided with the packed tyres via the overhead conveyor and the other three vulcanisation presses are dependant from the hand or electrical trucks.

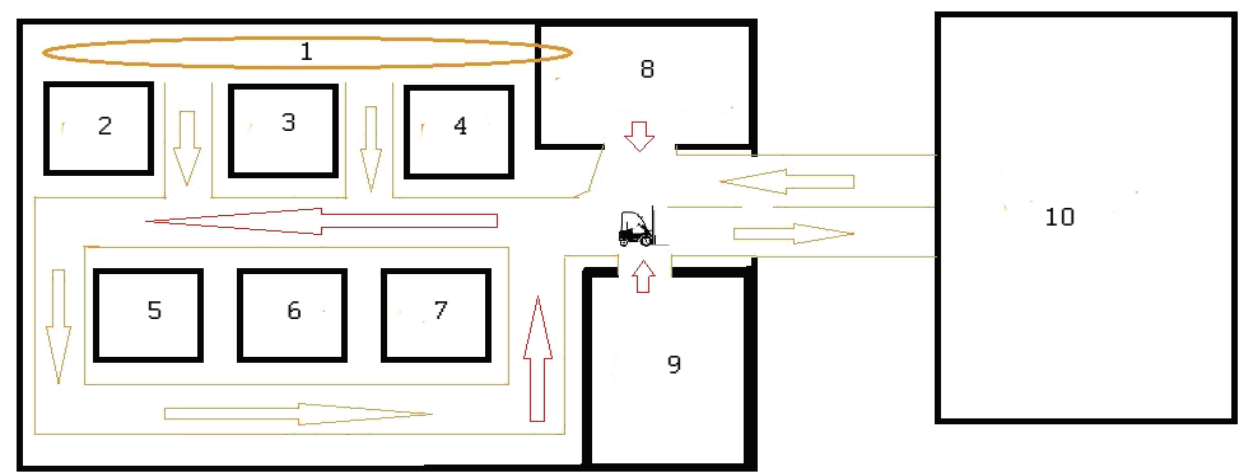

Fig. 1. OTR tyres production system structure: 1 - overhead conveyor; 2-7 - presses; 8- packing station; 9 - bead wire warehouse; 10 - treaded rubber and tyres warehouse. Source: authors

Analysing the above graph one can notice that there might be congested traffic on the way between the vulcanisation presses, since transport road is narrow and it is used by the trucks transporting finished goods from six presses and trucks transporting goods to the presses. In case of a breakdown of one of the trucks, the driver informs the department manager about the fact and the manager looks for a spare means of transport in other departments and reports the breakdown to the maintenance workshop. The situation may get worse of the truck breakdown occurs in more than one department at the same time.

When the production in some departments is not fluent, all means of transport are not equally busy. Using only $50 \%$ of the available means of transport results in higher maintenance and exploitation costs.

Taking the data about the usage of internal means of transport and the remarks about the work into consideration, a process of designing a new system of internal transport at OTR tyres production has been conducted. The project is based on a slight modernisation of transport processes, without a significant interference with the production process. It relies on the circular system, which is more efficient and fluent than the horizontal roll-on/ rolloff system. Production process has been changed with regards to bead wire warehousing which was shifted to the centre of production floor and constitutes an integral part of tyres packing stations, which were also shifted to the centre of the floor. Vulcanization presses remained where they were, only the presses 1, 2 and 3 were moved to the inside of the axis. The overhead conveyor was shifted to the line situated in the centre of the production floor and it now leads to the tyre packing station through the vulcanisation presses. Transport roads are now circular, and the roads with congested traffic have an extra two-way lane. Such a solution allows for passing by another truck which is currently being loaded or is broken.

The project also suggests which means of transport should be used for which activities, so the transport of bellows takes place via the overhead conveyor, and finished goods are 
transported by the trucks only. Thanks to this solution the transport system is kept in order and transport layout is not collisional.

New project structure of internal transport of OTR tyres production system is shown in Fig. 2.

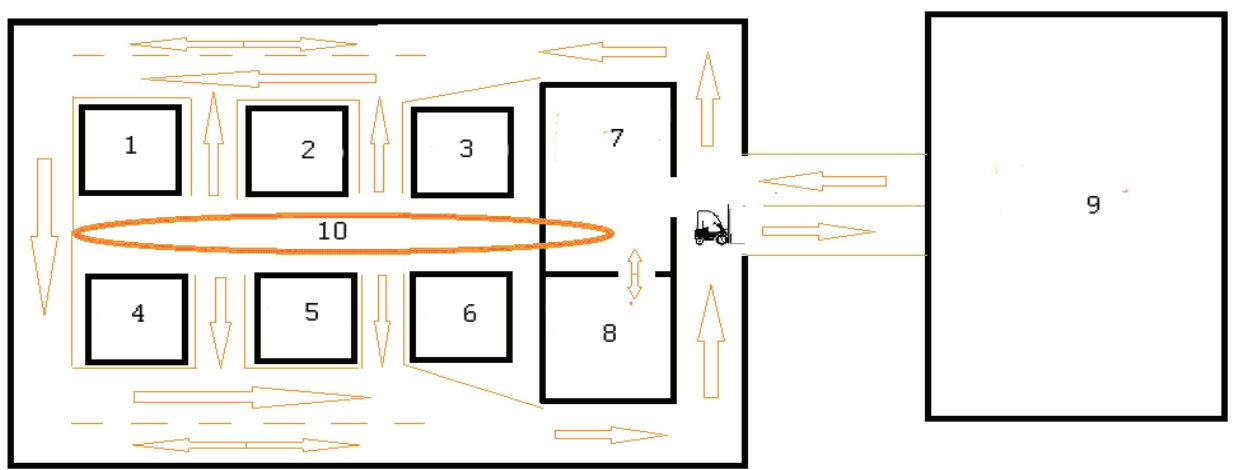

Fig. 2. New structure of OTR tyres production system: 1-6 - presses; 7 - packing station; 8 - bead wire warehouse; 9 - treaded rubber and tyres warehouse; 10 - overhead conveyor. Source: authors

A preparatory analysis of modernisation of the close transport process at the OTR tyres production may be conducted with SWOT analysis (Strengths, Weaknesses, Opportunities, Threats) - Table 2, which may point out both strengths and weaknesses of the proposed solution.

Table 2. SWOT analysis for the project of new system of internal transport in OTR tyres production. Source: authors

\begin{tabular}{|c|c|c|}
\hline & Positive factors & Negative factors \\
\hline & Strengths & Weaknesses \\
\hline 节 & $\begin{array}{l}\text { - shortening of production time, } \\
\text { - using one means of transport for a given } \\
\text { process, } \\
\text { - maintaining order, } \\
\text { - eliminating collisions from the transport } \\
\text { ways, } \\
\text { - decreasing a risk of congested traffic in } \\
\text { the transport process, }\end{array}$ & $\begin{array}{l}\text { - longer transport ways for transporting } \\
\text { finished goods, } \\
\text { - increasing exploitation costs, } \\
\text { - one direction of movement for all means } \\
\text { of transport, } \\
\text { - dependence on one means of transport, }\end{array}$ \\
\hline \multirow[b]{2}{*}{ 䎡 } & Opportunities & Threats \\
\hline & $\begin{array}{l}\text { - production increase, } \\
\text { - decrease of production costs, } \\
\text { - easy production process, } \\
\text { - innovative system, } \\
\text { - increasing production flexibility, } \\
\text { - increasing competitiveness, }\end{array}$ & $\begin{array}{l}\text { - the system may not prove right, } \\
\text { - delays in the realization of orders, } \\
\text { - the costs of system implementation may } \\
\text { be too high, }\end{array}$ \\
\hline
\end{tabular}

\section{Conclusion}

Internal transport is an indispensable element of production and warehousing processes. Modernisation of transport systems is one of the elements, the improvement of which may be a cheap and easy way to improve a production process and to decrease its costs [7-10]. The modernisation of current internal transport system at OTR tyres production requires certain funds. Also the number of cost studies and analyses should be made, since they can 
answer the question whether the implementation of the project will pay off on the first place. But from the perspective of time analysis, the modernisation of the system is highly advisable, as it shortens the production time of the tyre (from one warehouse to another) down to 40 minutes in a worst case, the current time (in the optimistic variant) being 50 minutes. The big bulk of material does not allow us to include the detailed calculations).

The transport project described has many advantages, such as: no congested traffic on the roads; the roads do not cross with each other, what eliminates the risk of collision; bead wire warehouse is situated close to the packing station; it makes transport more effective; shortens transport time, and makes the whole system easier. Though, there are some weaknesses of the project: it makes a transport way longer, it forces one-way traffic of the trucks and, in special cases, and transport of a finished tyre from the press can take longer.

This paper is supported by the research project "From horse-drawn railway to intermodal transport" within Visegrad Fund.

\section{References}

1. Z. Korzeń, Logistyczne systemy transportu bliskiego i magazynowania. Infrastruktura, technika, informacja (Poznań: Instytut Logistyki i Magazynowania w Poznaniu, Poland, 1998)

2. M. Jacyna, K. Lewczuk, M. Kłodawski, Journal of KONES, Powertrain and Transport, BK 22, 3, 49-58 (2015)

3. T. Govidaraj, E. Blanco, D. Bodner, L. Goetschalckx, L. McGinnis, G.P. Sharp, Proceeding of the 2000 IEEE International Conference on Systems, Man and Cybernetics, 1099-1104, 8-11 (Nashville, Tennessee, USA, 2000)

4. J. Fijałkowski, Transport Wewnętrzny w Systemach Logistycznych - Wybrane Zagadnienia (Warszawa: Oficyna Wydawnicza Politechniki, Poland, 2000)

5. W. Wawrzyński, M. Jacyna, Journal of KONES, Powertrain and Transport 22, 4, 319-327 (2015)

6. J.L. Chen, M.C. Chen, Ch.W. Chen, Y.Ch. Chang, Computer Communications 30, 2070-2086 (2007)

7. S. Krzyżaniak, et al., Organizacja i monitorowanie procesów magazynowych (Poznań: Instytut Magazynowania i Logistyki, Poland, 2014)

8. R. Raczyk, Środki transportu bliskiego i magazynowania (Poznań: Wydawnictwo Politechniki Poznańskiej, Poland, 2013)

9. Ł. Wojciechowski, A. Wojciechowski, T. Kosmatka, Infrastruktura magazynowa i transportowa (Poznań: Wyższa Szkoła Logistyki, Poland, 2009)

10. D. Pyza, Archives of Transport 21, 3-4, 125-148 